Economic History or History of Economics?

A Review Essay on Sylvia Nasar's

Grand Pursuit: the Story of Economic Genius

by

Orley Ashenfelter, Princeton University

The Griswold Center for Economic Policy Studies

Working Paper No. 225, January 2012 


\section{Economic History or History of Economics? A Review Essay on Sylvia Nasar's Grand Pursuit: the Story of Economic Genius}

\section{Orley Ashenfelter ${ }^{*}$}

In this essay I review Sylvia Nasar's long awaited new history of economics, Grand Pursuit. I describe how the book is an economic history of the period from 1850-1950, with distinguished economists' stories inserted in appropriate places. Nasar's goal is to show how economists work, but also to show that they are people too-with more than enough warts and foibles to show they are human! I contrast the general view of the role of economics in Grand Pursuit with Robert Heilbroner's remarkably different conception in The Worldly Philosophers. I also discuss more generally the question of why economists might be interested in their history at all.

\section{Introduction}

Grand Pursuit is Sylvia Nasar's long awaited new book project on the history of economics. The author of A Beautiful Mind, the blockbuster 1998 biography about Nobel Prize winner John Nash, Nasar is now a professor of journalism at Columbia University. The movie made from the book in 2001 was showered with Academy Award attention (even the sound track was nominated for an Oscar), and the interaction of book and movie led to a second wave of attention for both. Naturally, the success of $A$ Beautiful Mind has raised some very high expectations for Nasar's new project.

As it turns out the reaction to Grand Pursuit has been both muted and mixed. To some extent this reflects reader expectations, as the book's purpose remains unclear to many people even after they have finished it. As Bob Solow remarked in his review in The New Republic, "I thought I knew what this book was going to be about when I started it, but by the time I came to the end I was no longer sure."

I think Grand Pursuit does have a clear purpose, but, frankly, it is a little embarrassing to acknowledge it. The book is a kind of generous homage to economic analysis and those who practice it, and its goal is to explain what economists do and how they do it to a broad audience. Like the good journalist she is, however, Nasar knows she needs a hook in order to capture readers who, let's face it, see economists as far less useful than dentists, and perhaps even more boring. ${ }^{1}$ In fact, she uses two hooks. First, she has written an economic history of the period from roughly 1850 to 1950, and then

\footnotetext{
*Ashenfelter: Princeton University, Princeton, NJ. I am grateful to Janet Currie, John Eatwell, Angus Deaton, and John Pencavel for comments on an earlier draft of this review, and to Ming Gu for assistance.

${ }^{1}$ This is a partial quote from John Maynard Keynes, who actually said, "If economists could manage to get themselves thought of as humble, competent people on a level with dentists, that would be splendid."
} 
inserted her cast of economic characters into this history in the context of the economic policies of the day. The result is that economists like John Maynard Keynes, Irving Fisher, or Joan Robinson appear in several places in the book, rather than in a separate chapter. Second, Nasar shows that economists are people too! And, as such, they are sometimes characters who are actually quite interesting to read about. Some have extraordinary sex lives (Keynes), dreadful table manners (Keynes), and are antiSemitic (Keynes). Others have extraordinary families (Marx lived with two wives and had children with both, Robinson was in a ménage-a-trois with her collaborators on The Economics of Imperfect Competition), while others had very odd political inclinations (Fisher wrote 3 books promoting Prohibition!).

Before discussing what Grand Pursuit does, I think it is important to make clear what it does not do. First, despite some publishers' expectations, this book is not a modern update of Robert Heilbroner's The Worldly Philosophers. Mistakenly thinking at first that Nasar's book was a Heilbroner knock off, I started to read Grand Pursuit by turning to the chapter on Irving Fisher, expecting a compact summary of his life and work. Although there is an early chapter where Fisher appears in some depth, he also appears in several other chapters in Grand Pursuit, including one highlighting the relation between Fisher and Keynes during the Great Depression. My advice? It is far easier to read this book as you would a novel or an economic history-from cover to cover.

Second, Nasar has a leisurely style of writing that can sometimes infuriate a reader before it gets to any real point. I once asked Nasar why she had an entire, self-contained chapter on the eminent game theorist Lloyd Shapley in A Beautiful Mind. Her answer? "Do I actually have a whole chapter about him?" It is easy to get the feeling that, in some places, less might have actually been more.

\section{The Main Characters}

Figure 1 contains a list of the main characters in Grand Pursuit, but this by no means exhausts the entire set of characters that appear here and there. These characters range all the way from Ho Chi Minh, who was a dishwasher in the French Hotel that Keynes inhabited during the negotiation of the Treaty of Versailles, to more important roles for Canadian Jacob Viner, American Robert Solow, Hungarian Nicholas Kaldor, Briton Frank Ramsey, and Austrians Fritz Machlup and Ludwig von Mises.

Although Nasar uses Dickens's view of the conditions of London as a foil to start her story, the real play begins with Karl Marx and Friedrich Engels. Engels receives considerably more attention than is usual because, in Nasar's telling of the story, Engels serves as the essential entrepreneur behind Marx's work. Indeed, like many real people (and some economists), Marx appears to have been a major procrastinator with a strong interest in wine and food, and a complex family life. Nasar makes a good case that the final burst of energy that produced Das Kapital was provoked by the opportunity for relevance posed by the British financial panic of 1866 and by Engels having lost his patience to finance him. 
Using Marx as an initial foil provides Nasar with a good story, but also with a fine straw man. Marx was the last really successful economist whose predictions resembled the so-called "Iron Law of Wages." In this framework, labor is supplied perfectly elastically in the long run at the subsistence wage. The mechanism that enforces this was population growth for Malthus and Ricardo; when times are good population increases and otherwise population declines. For Marx the matter is more complex, but the result is the same: Increased demand for labor and productivity growth never leads to a permanent increase in living standards for workers.

One interesting theme in Grand Pursuit, which I doubt Nasar intended, is the extent to which she shows that most (but not all) economists rely on armchair empirical work. Although the famous Chapter 10 of Das Kapital provides the evidence Marx musters for the squalid conditions of Victorian factory workers, it appears that Marx did not himself ever visit any factory. Regardless, in his day it seems to have been widely accepted that wages were stagnant, the primary prediction of the "Iron Law." In retrospect, we know this theory was beaten not just by another theory, but by the facts. Wages did increase and theoretical modifications, which are still under way, were in order for both the theory of long run labor supply and demand.

Nasar's long discussion of Alfred Marshall does emphasize his fascination with facts and evidence. It also emphasizes the importance of his Principles of Economics for developing the familiar apparatus of supply and demand we use today. But I also think it is driven by the story of a love affair. In A Beautiful Mind John Nash had Alicia, his great love, and in Grand Pursuit Alfred Marshall has Mary. The basic Marshallian family problem will seem remarkably familiar to graduate students today, where it is now known as the "Two-Body Problem." Having been a star student at Cambridge, Marshall held a coveted Fellowship at St. John's, while Mary, one of the first women to attend Cambridge, was a college lecturer. At first it would seem the two-body problem was solved. Except that, were Marshall to marry, he would have to give up his Fellowship. Indeed, in 1877 he did just that and resigned his position at St. John's. With a stroke of great timing, Marshall was offered the post as Principal of the University of Bristol, the first of the co-educational red brick universities, where the newly married couple worked jointly on The Economics of Industry, and where Mary also lectured. The two-body problem was solved and the couple was happily married.

Another theme in Grand Pursuit that will intrigue economists today is the leisurely rate at which research work was pursued. Publish or perish was clearly not the model of the day. Marshall did not publish his Principles of Economics, on which his fame is based, until 1890, when he was 48 years old. Marx, at 49, was almost the same age when he published Das Kapital. It seems to have been the Americans, starting even with Irving Fisher in the $19^{\text {th }}$ century, who changed all this.

But Nasar's story stays mainly in Cambridge, with detours to London and Vienna, for much of its duration. Only at the very end do we take a brief trip to America and, almost as an afterthought, India. We primarily see economists through the work in "the book," whether it be The General Theory of Employment, Interest and Money; The Road to Serfdom, or The Theory of Economic Development. And all this is surrounded by the great events of the $20^{\text {th }}$ century: the First World War, the Great Depression, and the Second World War. 
The two characters who Nasar clearly falls for are Beatrice (Potter) Webb, and John Maynard Keynes. Webb, suffering from unrequited love, sidles up to Sydney as a substitute for someone she really wanted and could not have, famed politico Joseph Chamberlain. Tall, willowy, and lovely even as she aged, she seems also to have been a great manipulator and entrepreneur. She was a principal in the founding of both the London School of Economics and the Fabian Society. It is harder to make the case for her economics.

One feature of all the vignettes in Grand Pursuit that seems quirky, and may even annoy some, is the occasional appearance of KGB spies, Soviet apparatchiks, and, at the end, some Chinese Communist fellow travelers. It is important to remember that, for the British, the 1920s were not a period of prosperity. With high unused capacity and unemployment that continued into the 1930s many economists were fascinated with Stalin's Russia, and the great battle over capitalism versus socialism. The travels by Sydney and Beatrice Webb, as well as Joan Robinson, to Russia, and the apparent roles they played in descriptions of a successful economy, are all part of Nasar's story. But there are many other references to Harry Dexter White, an important US Treasury official for over a decade, who is described as a Russian spy. White worked closely with Jacob Viner in the Treasury, and also with Milton Friedman, and Paul Samuelson who, thank heavens, are not so labeled. Oskar Lange is not so lucky. ${ }^{2}$

But it is Keynes who provides much of the core of Nasar's story. Of all economists, John Maynard Keynes was one of the few to play a central role in all three of the big events of the $20^{\text {th }}$ century. The result is that the history of his life and the history of economic policy are closely intertwined. There is an eerie similarity of many current events to those that Keynes witnessed and participated in over a period of 30 years.

Keynes wrote The Economic Consequences of the Peace at just age 36, having been in Paris for the negotiations over who paid what in reparations at the end of World War I. In retrospect, what he wrote seems remarkably prescient, and relevant today for negotiations continuing in Europe over debt problems and financial integration. One could even argue that the European problems exposed in the First World War, and re-exposed in the Second World War, are still unsolved. But unlike both those events, whose resolution was a result of American intervention, there is not any prospect of that today.

Basically, the victors expected to negotiate a Treaty where they would be compensated not only for damage the Germans caused in the War, but also for the costs the victors incurred in going to War. This is a little like the rule in British, but not American, courts, where losers pay the winners their court costs. For Keynes the prevention of further wars in Europe required an integrated commercial and financial world, and he argued the Treaty would do the reverse.

Keynes is, of course, even more intimately connected with the history of the Great Depression. The economic history of that period, which Nasar covers in some detail, also has eerie similarities to the present. I am told by a reliable source that these chapters are making their rounds in the reading material at the White House.

\footnotetext{
${ }^{2}$ Solow (2011) questions the label Nasar applies to Lange.
} 
Herbert Hoover's first reaction in 1930, as President, to the start of the Depression was to propose tax cuts and to speed up infrastructure investment (including Boulder, now Hoover, Dam). Many economists approved of these policies, but they clearly did not stop the Depression. Franklin Roosevelt's reaction in 1933 was similar, and many economists also approved these policies, although they too did not stop the Depression's continuation. It appears that throughout this period both Presidents followed stop and start policies that seem remarkably familiar today.

Bretton Woods, and the end of World War II coincide with Keynes's death in 1946. Alongside the discussion of Keynes run discussions of the Austrian expats, Hayek and Schumpeter. Although Nasar provides their stories (and Schumpeter certainly has a good one), and some insight into their work and its importance, both characters remain distant. Perhaps, from where we sit today, it is simply too difficult to link their style of economic analysis to anything recognizable to a modern economist. Friedman, Samuelson, and Amartya Sen make brief appearances at the end of the book. Their inclusion seems almost an afterthought, designed to fill in at the end for the traditional discussion of Adam Smith, David Ricardo, and Thomas Malthus that was not provided at the beginning.

\section{Grand Pursuit vs. The Worldly Philosophers}

It is interesting to compare Grand Pursuit with Robert Heilbroner's The Worldly Philosophers; a book that no doubt some expected would be its model. There are similarities, but the differences strike me as larger.

The first edition of The Worldly Philosophers was published in 1953, and the last, the seventh, was published in 1999. This is a pretty long run for any author. Reported to have sold over 4 million copies, there are few books in economics that have reached so many people. In part the book's blockbuster sales represented assigned reading, as it did with me, when I bought the first revised edition (published in 1961) for an undergraduate class. It is sometimes said that The Worldly Philosophers was the best recruiting tool any economics department could design to fill its courses.

Although The Worldly Philosophers changed over the years, it remained remarkably similar through its seven editions over 46 years. The $7^{\text {th }}$ edition has an added chapter on Joseph Schumpeter, which is not in the second edition that I bought. But otherwise the book, apart from some tinkering with the writing and a concluding chapter that might be read as a denouement (perhaps for both the book and its author-Heilbroner died in 2005), is quite similar.

The grand theme of The Worldly Philosophers is the discussion of how a society will understand the allocation of its resources. From this theme it is easy to see why it is important to study what economists write. What they write is the intellectual framework that will be used to rationalize whatever economic system exists. From this perspective economists are worldly philosophers, not worldly scientists. And big issues, like the role of socialism versus capitalism, are at the center of the discussion. 
Ironically, the final chapter in Heilbroner's final edition announces the end of the worldly philosophy. The decline of Communism throughout the world by 1999 seems to have left Heilbroner without a big theme. And so he asked (Heilbroner, 1999, p. 319), "If economics is not to be a science of society, what is to be its ultimate social usefulness? My answer is that its purpose is to help us better understand the capitalist setting in which we will most likely have to shape our collective destiny for the foreseeable future. Having for many years endorsed the ideas and objectives of democratic socialism, that is not an easy assertion for me to make." Wow, we are all capitalists now!

So what is the theme of Grand Pursuit? The book's subtitle is "The Story of Economic Genius." Admittedly, many of the characters in Grand Pursuit seem wacky, but not many of them strike me as real, actual geniuses. So I am not sure just how that theme makes any sense. I think Nasar intends the theme of her book to reflect the idea that economics can help us increase living standards, something the classical economists thought impossible. Written, as it was, mainly during the "great moderation," Grand Pursuit has arrived at an unfortunate moment. The US has not had any growth for several years, and many worry this may turn into the new normal. Optimism is in short supply.

It is interesting to see how the characters in The Worldly Philosophers differ from those in Grand Pursuit. Two of the most notable differences are characters who appear in the former but not the latter. Thorstein Veblen is one of these. Veblen does appear briefly in Grand Pursuit, but Nasar dismisses him as a 'sociologist." Veblen was actually a member of the German institutionalist school, as was Heilbroner himself. As Nasar notes, many of the founding members of the American Economic Association were members of this school of thought, and they stood in contrast to the English school of economists that form the basis for Nasar's story. Just like capitalism, this English style of economics is now dominant, so it is perhaps no surprise that Veblen got the ax.

Heilbroner also includes a group that he calls the "utopian socialists." This curious mixed bag includes Robert Owen, Count Henri de Rouvroy de Saint-Simon, Charles Fourier, and John Stuart Mill. These fascinating characters certainly do not fit into Nasar's conception of modern analytical economics. It is even possible that Heilbroner's pronouncement of the death of democratic socialism would have led him to delete them from his own book as well.

There are, of course, many people who do not make it into The Worldly Philosophers, but who are major players in Grand Pursuit. Chief among these are Sydney and Beatrice Webb, and Joan Robinson. More revealing, however, is that although Irving Fisher plays a major role in Grand Pursuit, he is almost completely absent from The Worldly Philosophers. Heilbroner mentions him only to note that Fisher had embarrassed himself by predicting a new permanent high for the stock market just before the Crash of 1929. As the primary American member of the English analytical style of economics Fisher provides a suitable replacement in Grand Pursuit for the role Veblen played in the Worldly Philosophers. 


\section{Why History of Economic Thought?}

After all this, it seems perfectly sensible to ask, what is the point? That is, why should any economist read about or study the history of economic thought? I do not think this is an easy question to answer. The reality is that the teaching of the history of economic thought has virtually disappeared from our education programs. In a survey done 10 years ago, Ted Gayer ((2002) reported that only 13 of the top 62 graduate economics programs reported offering any course in the history of economic thought in the previous five years. Among the top 20 departments, only four reported having offered such a course. It seems likely that these numbers have declined even further in the last decade.

Agnar Sandmo (2010), in a new and interesting analytical history of economic thought, has actually offered three answers to this basic question. First, he suggests, reading the history of economic thought can be fun. Fair enough, how does Grand Pursuit perform by this standard? By almost any standard, I would have to say "very well." Second, Sandmo suggests, learning about the history of economic thought should be part of a liberal education. I am always uncomfortable about anyone prescribing what makes a "liberal education." For example, I think that a liberal education should include a basic understanding of statistics, but I have never found many people who agree with me. Still, on this criterion, Grand Pursuit does a good job of outlining some of the economic history in the US and Europe that is relevant even today. But Nasar's analysis of the history of economic thought will leave many economists scratching their heads.

Finally, Sandmo suggests that the study of the history of economic thought shows our students that economic analysis is not a static field but, as he puts it, an evolving one. This is no doubt true if we limit ourselves to what most of us know as microeconomics, but is it equally true of the study of aggregate or macroeconomics? Reading Grand Pursuit raises as many questions as it answers about just where the pursuit has led.

\section{References}

Gayer, Ted 2002. "Graduate Studies in the History of Economic Thought." History of Political Economy, 34(Annual Supplement): 35-61.

Heilbroner, Robert 1961. The Worldly Philosophers: The Lives, Ideas, and Times of the Great Economic Thinkers. New York: Simon Schuster.

Heilbroner, Robert 1999. The Worldly Philosophers: The Lives, Ideas, and Times of the Great Economic Thinkers. New York: Simon Schuster.

Nasar, Sylvia 2011. Grand Pursuit: The Story of Economic Genius. New York: Simon and Schuster.

Sandmo, Agnar 2010. Economics Evolving: A History of Economic Thought.

Princeton, New Jersey: Princeton University Press.

Solow, Robert 2011. "Working in the Dark." The New Republic, 242(15): 26-30. 


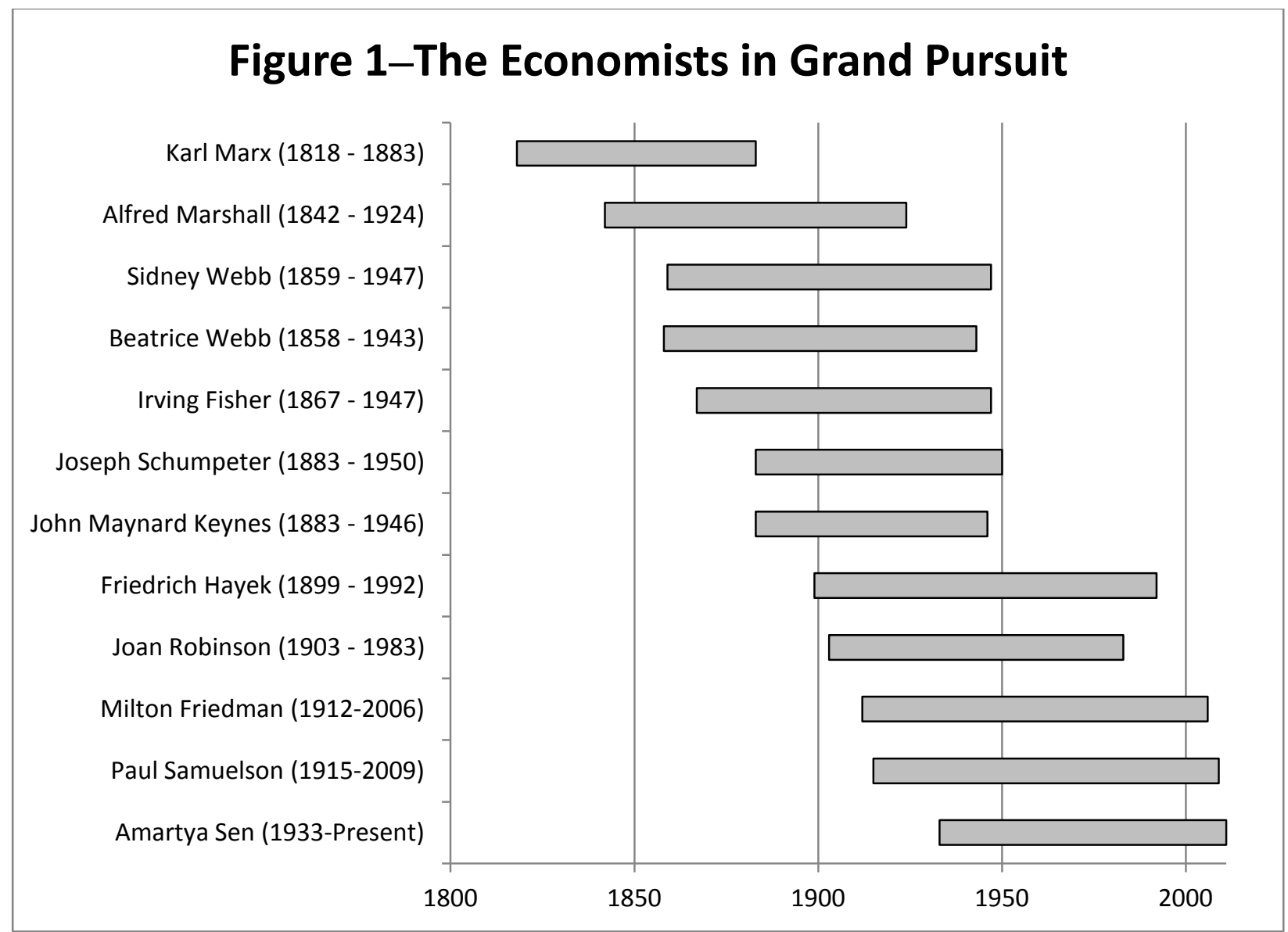

